\title{
Suistalinable

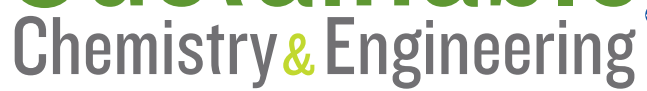 \\ Electrodeposition of Unary Oxide on a Bimetallic Hydroxide as a Highly Active and Stable Catalyst for Water Oxidation
}

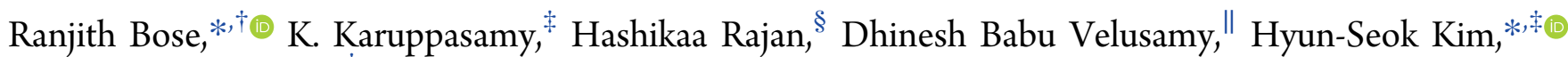 \\ and Akram Alfantazi*, ${ }^{*}$

\begin{abstract}
${ }^{\dagger}$ Department of Chemical Engineering, Khalifa University, Abu Dhabi, United Arab Emirates
${ }^{\ddagger}$ Division of Electronics and Electrical Engineering, Dongguk University-Seoul, Seoul 04620, Republic of Korea

${ }^{\S}$ Department of Chemical Engineering, Hanyang University, 222 Wangsimni-ro, Seong dong-gu, Seoul 04763, Republic of Korea

"Division of Physical Sciences and Engineering, King Abdullah University of Science and Technology (KAUST), Thuwal, Kingdom of Saudi Arabia
\end{abstract}

\section{Supporting Information}

\begin{abstract}
For industrial-scale water electrolysis, development of a highly stable and active oxygen evolution reaction (OER) electrocatalyst is highly demanded. In this study, we report an efficient OER electrocatalyst of $\mathrm{CeO}_{x}$ (unary oxide) and $\mathrm{NiFe}-\mathrm{OH}$ (bimetallic hydroxide) electrochemically deposited on a macroporous nickel foam substrate. The synthesized electrocatalyst exhibits remarkably improved OER performance by reaching a current density of $100 \mathrm{~mA} \mathrm{~cm}{ }^{-2}$ at a low overpotential of $280 \mathrm{mV}$, which is quite superior to that of most of the previously reported non-noble-metalbased OER electrocatalysts. Furthermore, the developed catalyst demon-

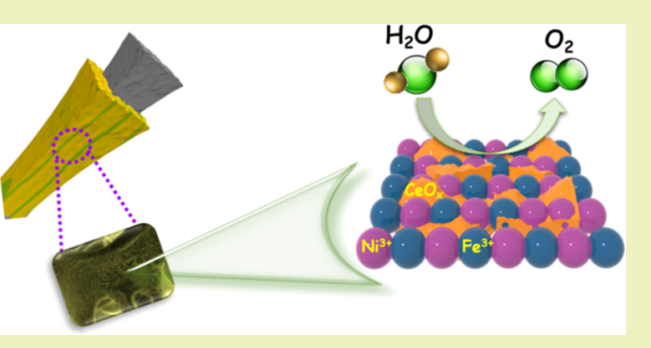
strated a minor Tafel slope of $43.2 \mathrm{mV} \mathrm{dec}^{-1}$ with good stability under a large current at a continuous operation of $80000 \mathrm{~s}$ in a strong alkaline electrolyte. Experimental observations revealed that the combination of $\mathrm{CeO}_{x}$ and $\mathrm{NiFe}-\mathrm{OH}$ accelerates the electroadsorption energies between the electrocatalyst surface and oxygen intermediates, considerably contributing to the OER enhancement. These results undoubtedly represent an important milestone toward the development of efficient OER electrocatalysts for applications as industrial water electrolyzers.
\end{abstract}

KEYWORDS: electrodeposition, heterogeneous catalysis, oxygen evolution, water electrolysis

\section{INTRODUCTION}

Electrochemical water splitting is considered to be one of the best methods to produce hydrogen $\left(\mathrm{H}_{2}\right)$, and it is proposed to be a sustainable route to convert water into hydrogen $\left(\mathrm{H}_{2}\right)$ and oxygen $\left(\mathrm{O}_{2}\right){ }^{1-6}$ The water splitting reaction typically involves the combination of two half-cell reactions: oxygen evolution reaction (active oxygen evolution reaction (OER): $4 \mathrm{OH}^{-} \rightarrow$ $\mathrm{O}_{2}+2 \mathrm{H}_{2} \mathrm{O}+4 \mathrm{e}^{-}, V_{\text {OER }}=-0.40 \mathrm{~V}$ vs reversible hydrogen electrode (RHE)) and hydrogen evolution reaction (HER: $2 \mathrm{H}_{2} \mathrm{O}+2 \mathrm{e}^{-} \rightarrow \mathrm{H}_{2}+2 \mathrm{OH}^{-} V_{\mathrm{HER}}=-0.83 \mathrm{~V}$ vs RHE). ${ }^{7-10}$ From the kinetic viewpoint, OER, also referred to as water oxidation, is a diverse process because it is a multiprotoncoupled four-electron-transfer reaction and restricts the overall efficiency of water splitting. ${ }^{11-14}$ Hence, the development of efficient OER catalysts has become an important frontier for overall water splitting as well as for overcoming the sluggish OER kinetics. Recently, catalysts based on cerium ( $\mathrm{Ce}$ ) and its oxide $\left(\mathrm{CeO}_{2}\right)$ have attracted considerable attention as economic alternatives to ruthenium $(\mathrm{Ru})$ - and iridium (Ir)based catalysts for OER. ${ }^{15-23}$ Moreover, from the results of previous studies, it is promising that $\mathrm{CeO}_{2}$-based catalysts, such as $\mathrm{CeO}_{2} / \mathrm{Ni}(\mathrm{OH})_{2}, \mathrm{Ni}_{x} \mathrm{Ce}_{y} @ \mathrm{CP}, \mathrm{NiFeCeO}_{x}, \mathrm{FeOOH} /$ $\mathrm{CeO}_{2}$, and $\mathrm{CeO}_{2} / \mathrm{NiO}$, play a crucial role in the OER activity. All of these catalysts demonstrate an analogous phenomenon:
When $\mathrm{CeO}_{2}$ is alloyed with transition metals, it exhibits higher catalytic activity, corresponding to the higher storage capability of oxygen and generation of strong electronic interactions between different components. ${ }^{17-19,23-25}$ Currently, $\mathrm{CeO}_{2}$ doped transition metal oxide OER catalysts are predominantly prepared by solution-based methods, including sol-gel synthesis, colloidal synthesis, zeolitic imidazolate frameworks, and solvo- (or) hydrothermal methods. ${ }^{19-24}$ However, solution-based methods pose some serious issues related to the catalyst efficacy. Disadvantages of solution-based systems include (i) lack of control of the nanomaterial size, (ii) nonuniformity of the loading and distribution of the catalyst on a conductive substrate (such as carbon cloth and nickel foam, nickel foam (NF)), (iii) no monitoring of the crystal growth during the synthesis. In addition, this solution-based system is not recommended for industrial applications due to the complicated synthesis procedures.

To overcome these issues, the electrodeposition technique for the synthesis of OER catalysts comes into play. This technique permits the control of the degree of irreversibility of

Received: June 20, 2019

Revised: July 31, 2019

Published: August 27, 2019 
the growth process and exploits interatomic interactions of the growth process by controlling the potential. Furthermore, it is a simple process, and it can be significantly promoted for industrial applications. ${ }^{26}$ Thus far, researchers have employed electrodeposition, and studies have reported an electrodeposited $\mathrm{CeO}_{2}$ electrocatalyst with a composition of a unary oxide/hydroxide/oxyhydroxide such as $\mathrm{NiCeO}_{x}$, $\mathrm{FeOOH} / \mathrm{CeO}_{2}$, and $\mathrm{CeO}_{2} / \mathrm{Ni}(\mathrm{OH})_{2} \cdot{ }^{15,17,18}$ Nevertheless, it requires a further enhancement in its performance. For instance, Jia et al. have prepared gold ( $\mathrm{Au}$ )-supported cerium-doped $\mathrm{NiO}_{x}$ as a water oxidation catalyst and reported the clear improvement in the OER performance via the enhancement of the dopant, i.e., cerium active species; however, $\mathrm{NiCeO}_{x}$ is deposited on an expensive material such as the $\mathrm{Au}$ substrate, which is also a flat substrate. Previous studies have reported that a flat substrate comprises restricted available active sites and only scarce farthest layers of the substrate are in contact with the electrolytes. ${ }^{26}$ Besides, the effervescence generated due to $\mathrm{O}_{2}$ evolution especially under high current densities be opt to gather on flat substrates, thereby restricting the mass transport. ${ }^{26,27}$ To overcome these obstacles, a nonplanar substrate with porous morphology will be highly desirable to provide a higher surface area. Based on structural engineering, the OER activity of transition metal oxides can be further improved by using multimetallic oxides, which are advantageous due to synergistic metal-metal interactions. ${ }^{15,26}$ In this regard, recently, Obata et al. have depicted this metal-metal interaction by depositing a $\mathrm{CeO}_{x}$ layer on $\mathrm{NiFeO}_{x}{ }^{25}$ Nevertheless, scarce enhancement of the OER activity is observed for large-area-coated layers, which restricts the contact between the electrolyte solution and active site centers; thus, it is crucial to focus on boosting the catalytic performance. In summary, a versatile, efficient method to synthesize $\mathrm{CeO}_{2}$-based catalysts for use in industrial applications is still lacking.

In this work, we developed a composite type of catalyst $\mathrm{CeO}_{x} / \mathrm{NiFe}-\mathrm{OH}$ on a three-dimensional (3D) macroporous nickel foam (NF) substrate, which combines the features of $\mathrm{CeO}_{x}$ and $\mathrm{NiFe}-\mathrm{OH}$, such as outstanding mass-transfer properties, enhanced active sites, energetics for the OER, and mechanical robustness. $\mathrm{CeO}_{x} / \mathrm{NiFe}-\mathrm{OH}$ was synthesized by a two-step strategy starting with the preparation of $\mathrm{NiFe}-\mathrm{OH}$ by facial electrodeposition, followed by anodic electrolysis to introduce the $\mathrm{CeO}_{x}$ species into the $\mathrm{NiFe}-\mathrm{OH}$ coated film. The resulting composite catalyst $\mathrm{CeO}_{x} / \mathrm{NiFe}-\mathrm{OH}$ exhibited excellent OER activity with a current density of $100 \mathrm{~mA} \mathrm{~cm}^{-2}$ at an overpotential of $280 \mathrm{mV}$ and the lowest Tafel slope of 43.2 $\mathrm{mV} \operatorname{dec}^{-1}$. Notably, this composite catalyst exhibited outstanding electrochemical performance without any compromise in the magnitudes of the overpotential as well as the Tafel slope, outperforming previously reported catalysts. In addition, this composite catalyst did not exhibit any noticeable deactivation up to $80000 \mathrm{~s}$ of continuous electrolysis, demonstrating outstanding operational stability.

\section{RESULTS AND DISCUSSION}

The OER electrocatalysts of amorphous $\mathrm{CeO}_{x} / \mathrm{NiFe}-\mathrm{OH}$ films on NF substrates were prepared by a facile, two-step electrodeposition technique. In the current experiment, NF was selected as the substrate primarily because it promotes rapid interfacial electron charge transfer between the water oxidation catalyst and aqueous electrolyte. ${ }^{23,28}$ Furthermore, it exhibited an extremely high specific surface area and integrity compared with those of conventional free-standing substrates. $^{26}$ Typically, a NiFe-OH-based film was initially deposited on the NF electrode by the cathodic electrolysis of $3 \mathrm{mM}$ nickel nitrate hexahydrate $\left(\mathrm{Ni}\left(\mathrm{NO}_{3}\right)_{2} \cdot 6 \mathrm{H}_{2} \mathrm{O}\right)$ and a 3 $\mathrm{mM}$ iron nitrate nonahydrate $\left(\mathrm{Fe}\left(\mathrm{NO}_{3}\right)_{3} \cdot 9 \mathrm{H}_{2} \mathrm{O}\right)$ deposition solution at a fixed cathodic voltage of $-1.0 \mathrm{~V}$ vs $\mathrm{Ag} / \mathrm{AgCl}$ for 300 s. Then, $\mathrm{CeO}_{x}$ was incorporated into the $\mathrm{NiFe}-\mathrm{OH} / \mathrm{NF}$ electrode by the application of a fixed anodic potential of +0.5 $\mathrm{V}$ vs $\mathrm{Ag} / \mathrm{AgCl}$ in an aqueous solution comprising $0.1 \mathrm{M}$ cerium nitrate $\left(\mathrm{Ce}\left(\mathrm{NO}_{3}\right)_{3}\right)$ and $0.1 \mathrm{M}$ ammonium acetate at a $\mathrm{pH}$ of 6.3. Notably, prior to $\mathrm{CeO}_{x}$ deposition, the ammonium acetate solution was bubbled with argon (Ar) for $1 \mathrm{~h}$ to eliminate the dissolved oxygen, and at that point, $0.1 \mathrm{M}$ $\mathrm{Ce}\left(\mathrm{NO}_{3}\right)_{3}$ was added. The above process not only eliminated the dissolved oxygen in solution but also prevented the formation of a colloidal suspension of ceria powder during deposition. $^{29}$ The complete sketch of the electrodeposition process and the film evaluation is schematically illustrated in Figure 1a and expressed as follows (eqs 1-3). ${ }^{26,29-31}$

Step-1: Electrodeposition of $\mathrm{NiFe}-\mathrm{OH}$ films on $\mathrm{NF}$

$$
\begin{aligned}
x \mathrm{Ni}^{2+}+ & y \mathrm{Fe}^{3+}+(2 x+3 y) \mathrm{NO}_{3}^{-}+7(2 x+3 y) \mathrm{H}_{2} \mathrm{O} \\
\rightarrow & \mathrm{Ni}_{x} \mathrm{Fe}_{y}(\mathrm{OH})_{(2 x+3 y)}+(2 x+3 y) \mathrm{NH}_{4}^{+} \\
& +9(2 x+3 y) \mathrm{OH}^{-}
\end{aligned}
$$

Step-2: Electrodeposition of $\mathrm{CeO}_{x}$ on $\mathrm{NiFe}-\mathrm{OH}$ films

$$
\begin{gathered}
2 \mathrm{Ce}\left(\mathrm{NO}_{3}\right)_{3}+6 \mathrm{CH}_{3} \mathrm{COONH}_{4}+\mathrm{H}_{2} \mathrm{O} \\
\rightarrow \mathrm{CeO}_{2}+\left(\mathrm{CH}_{3} \mathrm{COO}\right)_{3} \mathrm{Ce}+3 \mathrm{CH}_{3} \mathrm{COO}^{-}+6 \mathrm{NH}_{4} \mathrm{NO}_{3}
\end{gathered}
$$

$$
\left(\mathrm{CH}_{3} \mathrm{COO}\right)_{3} \mathrm{Ce}+2 \mathrm{H}_{2} \mathrm{O} \rightarrow \mathrm{CeO}_{2}+3 \mathrm{CH}_{3} \mathrm{COO}^{-}+4 \mathrm{H}^{+}
$$

Scanning electron microscopy (SEM) and transmission electron microscopy (TEM) images (Figure 1) were recorded to observe the morphologies of the prepared electrocatalysts. Figure $1 \mathrm{~b}, \mathrm{c}$ shows the SEM images of $\mathrm{CeO}_{x} / \mathrm{NiFe}-\mathrm{OH} / \mathrm{NF}$ under different magnifications: An extremely even morphology through the intact area was observed at lower magnification, whereas "ripple marks" were observed for the nanofilms at higher magnification (Figure 1c). This morphology will probably lead to an effortless mass transport (reactants and oxygen bubbles) during OER. In addition, such nanofilm catalysts can afford more accessible active sites and a considerably rougher surface, significantly decreasing the interaction between gas bubbles and the adhesion of the electrode surface; this decreased interaction and adhesion lead to the increased evolution of the adhered gas products; hence, it is advantageous for electrocatalytic gas evolution. ${ }^{18,26,32}$ The morphology of $\mathrm{CeO}_{x} / \mathrm{NiFe}-\mathrm{OH}$ deposited on NF catalysts was significantly different from that of $\mathrm{NiFe}-\mathrm{OH} / \mathrm{NF}$ and $\mathrm{CeO}_{x} /$ NF catalysts (Figure S1a,b). Figure 1d shows the highresolution TEM image of the as-synthesized $\mathrm{CeO}_{x} / \mathrm{NiFe}-\mathrm{OH}$ film and its corresponding selected-area electron diffraction (SAED) pattern. The as-synthesized $\mathrm{CeO}_{x} / \mathrm{NiFe-OH}$ film comprised a highly disordered structure, and typical lattice fringes were not detected, indicative of the amorphous phase of the as-prepared catalysts (Figure 1d). The inset of Figure 1d revealed a diffused halo SAED pattern, indicative of the absence of the nanocrystalline phase; this result confirmed the amorphous phase of the prepared electrocatalyst. ${ }^{26}$ To confirm 


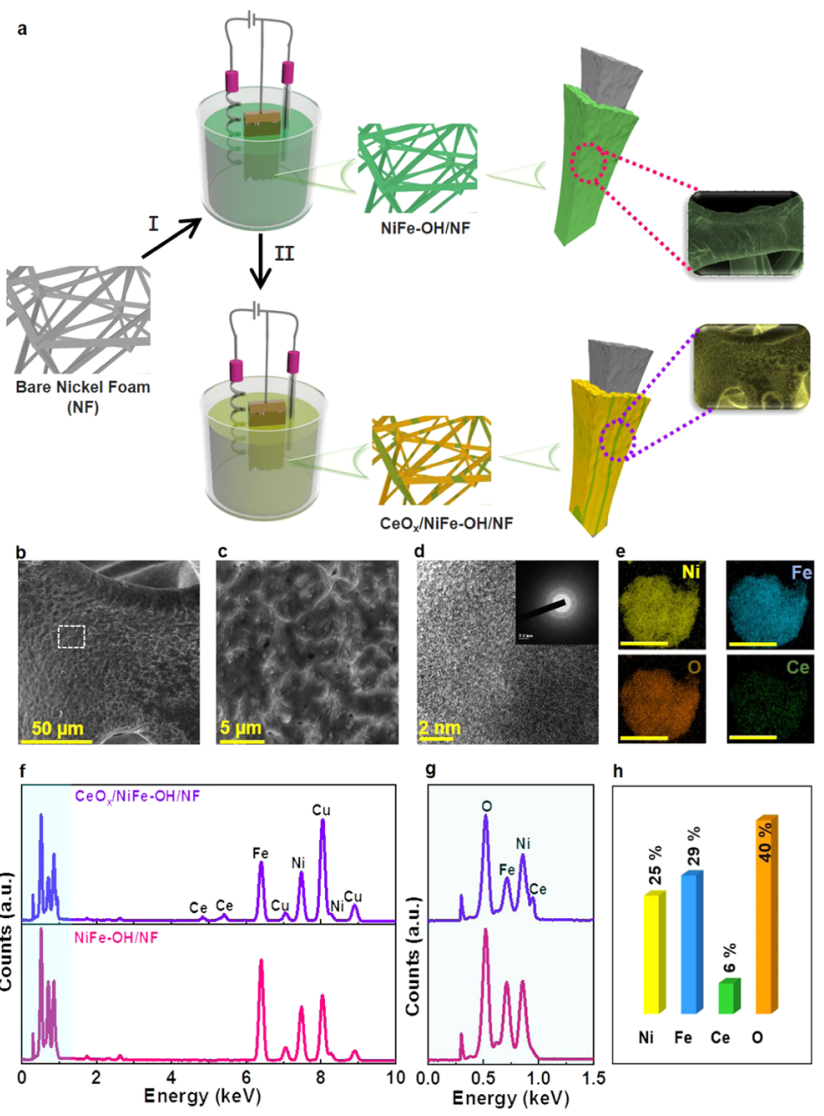

Figure 1. Fabrication and morphological studies of the $\mathrm{CeO}_{x} / \mathrm{NiFe}-$ $\mathrm{OH} / \mathrm{NF}$ catalyst. (a) Schematic of $\mathrm{CeO}_{x} / \mathrm{NiFe}-\mathrm{OH} / \mathrm{NF}$ catalyst preparation using the electrodeposition method, including cathodic electrolysis (step-I) followed by anodic electrolysis (step-II). Reference electrode: $\mathrm{Ag} / \mathrm{AgCl}$, counter electrode: Pt. (b, c) Scanning electron microscopy (SEM) images under different magnifications. (d) Transmission electron microscopy (TEM) image of a typical $\mathrm{CeO}_{x} / \mathrm{NiFe}-\mathrm{OH}$ catalyst (the inset shows the corresponding selectedarea electron diffraction (SAED) pattern). The TEM sample of the $\mathrm{CeO}_{x} / \mathrm{NiFe}-\mathrm{OH}$ catalyst was scratched off from $\mathrm{CeO}_{x} / \mathrm{NiFe}-\mathrm{OH} / \mathrm{NF}$. (e) Elemental energy-dispersive $\mathrm{X}$-ray spectroscopy (EDX) mapping for $\mathrm{Ni}, \mathrm{Fe}, \mathrm{Ce}$, and $\mathrm{O}$ recorded for the $\mathrm{CeO}_{x} / \mathrm{NiFe}-\mathrm{OH}$ catalyst. Scale bar: $100 \mu \mathrm{m}$. (f) The corresponding EDX spectrum. (g) Magnified EDX spectrum of the highlighted region in $(\mathrm{f})$. (h) Elemental atomic percentage estimated from the EDX spectrum.

the presence of $\mathrm{Ni}, \mathrm{Fe}, \mathrm{Ce}$, and $\mathrm{O}$ and to identify the elemental distribution in $\mathrm{CeO}_{x} / \mathrm{NiFe}-\mathrm{OH} / \mathrm{NF}$, energy-dispersive $\mathrm{X}$-ray spectroscopy (EDX) and elemental mapping analyses were carried out. Figure $1 \mathrm{e}-\mathrm{h}$ shows the resultant images with the composition. Figure $\mathrm{S} 2 \mathrm{a}-\mathrm{c}$ shows the TEM and elemental mapping images of the bare $\mathrm{NiFe}-\mathrm{OH}$ catalyst. Pristine $\mathrm{NiFe}-$ $\mathrm{OH}$ comprised an amorphous phase with the presence of $\mathrm{Ni}$, $\mathrm{Fe}$, and $\mathrm{O}$, further confirming the uniform distribution of $\mathrm{NiFe}-\mathrm{OH}$ on $\mathrm{NF}$.

To validate the amorphicity of the prepared electrocatalyst, $\mathrm{X}$-ray diffraction (XRD) patterns were recorded in the $2 \theta$ range from 20 to $80^{\circ}$ (Figure 2a). As reported elsewhere, pristine NF is well known to exhibit broad Bragg's crystallographic peaks at $2 \theta=45.2,52.4$, and $76.9^{\circ} .^{23,26,28,33}$ From the XRD pattern shown in Figure $2 \mathrm{a}$, new crystalline peaks were not observed, reaffirming the fact that an amorphous phase is present; this result was in accordance with those obtained from TEM and SAED analyses. Previous studies have revealed that the amorphous nature of $\mathrm{CeO}_{x} / \mathrm{NiFe}-\mathrm{OH}$ on $\mathrm{NF}$ can afford a larger surface area and better electrical conductivity, thereby possibly enhancing its catalytic activity. ${ }^{10,26,28}$ To further examine the strong electronic-state interactions between $\mathrm{CeO}_{x}$ and $\mathrm{NiFe}-\mathrm{OH}, \mathrm{X}$-ray photoelectron spectroscopy (XPS) profiles of $\mathrm{CeO}_{x} / \mathrm{NiFe}-\mathrm{OH} / \mathrm{NF}, \mathrm{NiFe}-\mathrm{OH} / \mathrm{NF}$, and $\mathrm{CeO}_{x} /$ $\mathrm{NF}$ were recorded. Figure $2 \mathrm{~b}-\mathrm{f}$ shows the resultant electronic states of $\mathrm{Ce} 3 \mathrm{~d}, \mathrm{Fe} 2 \mathrm{p}, \mathrm{Ni} 2 \mathrm{p}$, and $\mathrm{O} 1 \mathrm{~s}$. The survey spectra clearly confirmed the presence of $\mathrm{Ni}, \mathrm{Fe}, \mathrm{Ce}$, and $\mathrm{O}$, suggesting the formation of $\mathrm{CeO}_{x} / \mathrm{NiFe}-\mathrm{OH} / \mathrm{NF}, \mathrm{NiFe}-\mathrm{OH} / \mathrm{NF}$, and $\mathrm{CeO}_{x} / \mathrm{NF}$ films. The Ni 2p XPS spectra of NiFe-OH and $\mathrm{CeO}_{x} / \mathrm{NiFe}-\mathrm{OH}$ (Figure 2c) were deconvoluted into four peaks, and higher-intensity peaks corresponded to $\mathrm{Ni}^{2+}$ and $\mathrm{Ni}^{3+}$. . Notably, the $\mathrm{Ni}^{2+}$ and $\mathrm{Ni}^{3+}$ peaks corresponding to the $\mathrm{CeO}_{x} / \mathrm{NiFe}-\mathrm{OH}$ catalyst were shifted to lower binding energies due to the incorporation of $\mathrm{CeO}_{x}$ on $\mathrm{NiFe}-\mathrm{OH}$, as compared to the $\mathrm{NiFe}-\mathrm{OH}$ catalyst, which is indicative of the strong electronic interactions between $\mathrm{CeO}_{x}$ and $\mathrm{NiFe}-\mathrm{OH}$. Furthermore, $\mathrm{Ni}^{3+}$ is typically believed to exhibit favorable catalytic active sites for water oxidation reactions. It was predominant in the electrocatalyst prepared herein. ${ }^{18,24}$ In this scenario, the ratio $\mathrm{Ni}^{2+} / \mathrm{Ni}^{3+}$ in $\mathrm{CeO}_{x} / \mathrm{NiFe}-\mathrm{OH}(0.81)$ was slightly changed in comparison with that in bare $\mathrm{NiFe}-\mathrm{OH}$ (0.89), which was denoted as the highest concentration of $\mathrm{Ni}^{3+}$ in $\mathrm{CeO}_{x} / \mathrm{NiFe}-\mathrm{OH}$ catalysts. $^{24}$ In the $\mathrm{Fe} 2 \mathrm{p}$ XPS spectra (Figure $2 \mathrm{~d}$ ), peaks were observed at $\sim 724.6 \mathrm{eV}\left(2 \mathrm{p}_{3 / 2}\right)$ and $\sim 711.7 \mathrm{eV}\left(2 \mathrm{p}_{1 / 2}\right)$, without dramatic changes in the line shape and peak position, confirming the presence of the Fe species as $\mathrm{Fe}^{3+}$ in both catalysts. ${ }^{17,34}$ Figure $2 \mathrm{e}$ shows the deconvoluted XPS spectra of Ce $3 \mathrm{~d}$. The Ce $3 \mathrm{~d}_{3 / 2}$ component was obtained at the binding energy peaks of $922-913$ and $903-893 \mathrm{eV}$, whereas it is obtained at $877-866 \mathrm{eV}$ in the case of Ce $3 \mathrm{~d}_{5 / 2}$ components of $\mathrm{CeO}_{x} / \mathrm{NiFe}-\mathrm{OH} / \mathrm{NF}$ and $\mathrm{CeO}_{x} / \mathrm{NF}$ films. ${ }^{18,19,23,24}$ These two strong signals confirmed the presence of $\mathrm{Ce}^{3+}$ and $\mathrm{Ce}^{4+}$ in both samples. Furthermore, the magnified view of the peak positions indicated that $\mathrm{Ce}^{4+}$ of $\mathrm{CeO}_{x} / \mathrm{NiFe}-\mathrm{OH} / \mathrm{NF}$ is significantly increased in comparison to $\mathrm{Ce}^{4+}$ of $\mathrm{CeO}_{x} / \mathrm{NF}$. The results strongly confirmed the significant electronic rearrangement between $\mathrm{CeO}_{x}$ and $\mathrm{NiFe}-$ $\mathrm{OH}$. The $\mathrm{O} 1 \mathrm{~s}$ signals corresponding to $\mathrm{CeO}_{x} / \mathrm{NiFe}-\mathrm{OH} / \mathrm{NF}$, $\mathrm{NiFe}-\mathrm{OH} / \mathrm{NF}$, and $\mathrm{CeO}_{x} / \mathrm{NF}$ were observed at 529.2, 530.8, and $532.4 \mathrm{eV}$, related to $\mathrm{Ce}-\mathrm{O}, \mathrm{Ni}-\mathrm{O}-\mathrm{Fe}$, and the adsorbed oxygen species (i.e., hydroxides and water molecules), respectively (Figure 2f). ${ }^{14,16,17,35,36}$ Its relevant deconvoluted spectra indicated that the $\mathrm{O} 1 \mathrm{~s}$ signal of $\mathrm{CeO}_{x} / \mathrm{NiFe}-\mathrm{OH} / \mathrm{NF}$ shifts to higher binding energies than those of $\mathrm{NiFe}-\mathrm{OH} / \mathrm{NF}$ and $\mathrm{CeO}_{x} / \mathrm{NF}$. The large positive shift of $\mathrm{O} 1 \mathrm{~s}$ in the catalyst samples was indicative of a possible in-depth electronic interaction between $\mathrm{CeO}_{x}$ and $\mathrm{NiFe}-\mathrm{OH}$, and this supposition was in agreement with previously reported results. ${ }^{17}$

The OER performance was examined in an $\mathrm{O}_{2}$-saturated 1 $\mathrm{M} \mathrm{KOH}(\mathrm{pH} \sim 13.8)$ solution at a scan rate of $5 \mathrm{mV} \mathrm{s}^{-1}$. For comparison, bare NF and $\mathrm{RuO}_{2}$ on glassy carbon (GC) were also examined under the same conditions. $\mathrm{CeO}_{x} / \mathrm{NiFe}-\mathrm{OH} /$ $\mathrm{NF}$ exhibited the best OER performance (Figure 3a). $\mathrm{CeO}_{x} /$ $\mathrm{NiFe}-\mathrm{OH} / \mathrm{NF}$ only required an overpotential $\left(\eta_{\mathrm{OER}}\right)$ of 249 $\mathrm{mV}$ to reach $20 \mathrm{~mA} \mathrm{~cm}{ }^{-2}$; this value is considerably less than those of $\mathrm{NiFe}-\mathrm{OH} / \mathrm{NF}(270 \mathrm{mV}), \mathrm{CeO}_{x} / \mathrm{NF}(351 \mathrm{mV})$, bare $\mathrm{NF}(410 \mathrm{mV})$, and $\mathrm{RuO}_{2} / \mathrm{GC}(449 \mathrm{mV})$. Furthermore, to attain a current density of $100 \mathrm{~mA} \mathrm{~cm}^{-2}$, the $\mathrm{CeO}_{x} / \mathrm{NiFe}-\mathrm{OH} /$ NF film required a comparatively low overpotential of $280 \mathrm{mV}$, whereas the $\mathrm{NiFe}-\mathrm{OH} / \mathrm{NF}$ and $\mathrm{CeO}_{x} / \mathrm{NF}$ electrodes required overpotentials of 310 and $392 \mathrm{mV}$, respectively (Figure $3 \mathrm{~b}$ ). 

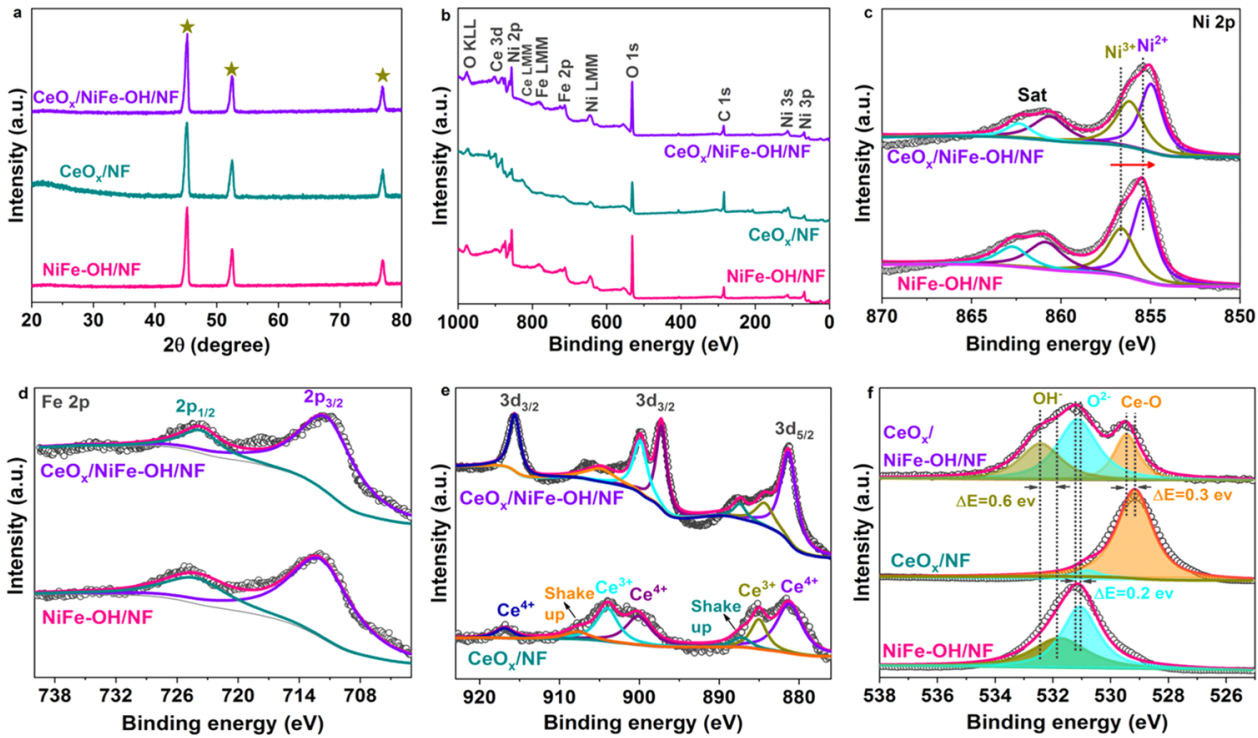

Figure 2. Physical and chemical characterization of $\mathrm{CeO}_{x} / \mathrm{NiFe}-\mathrm{OH} / \mathrm{NF}$. (a) XRD patterns of the as-prepared catalysts. The pentagram symbol represents the diffraction peaks of nickel foam. (b) XPS survey spectra. High-resolution XPS spectra of Ni 2p (c), Fe 2p (d), Ce 3d (e), and O 1s (f). Dashed gray lines denote the peak shift in the Ni $2 \mathrm{p}$ and $\mathrm{O} 1 \mathrm{~s}$ spectra, while no peak shift was observed in the Fe $2 \mathrm{p}$ and Ce $3 \mathrm{~d}$ spectra.
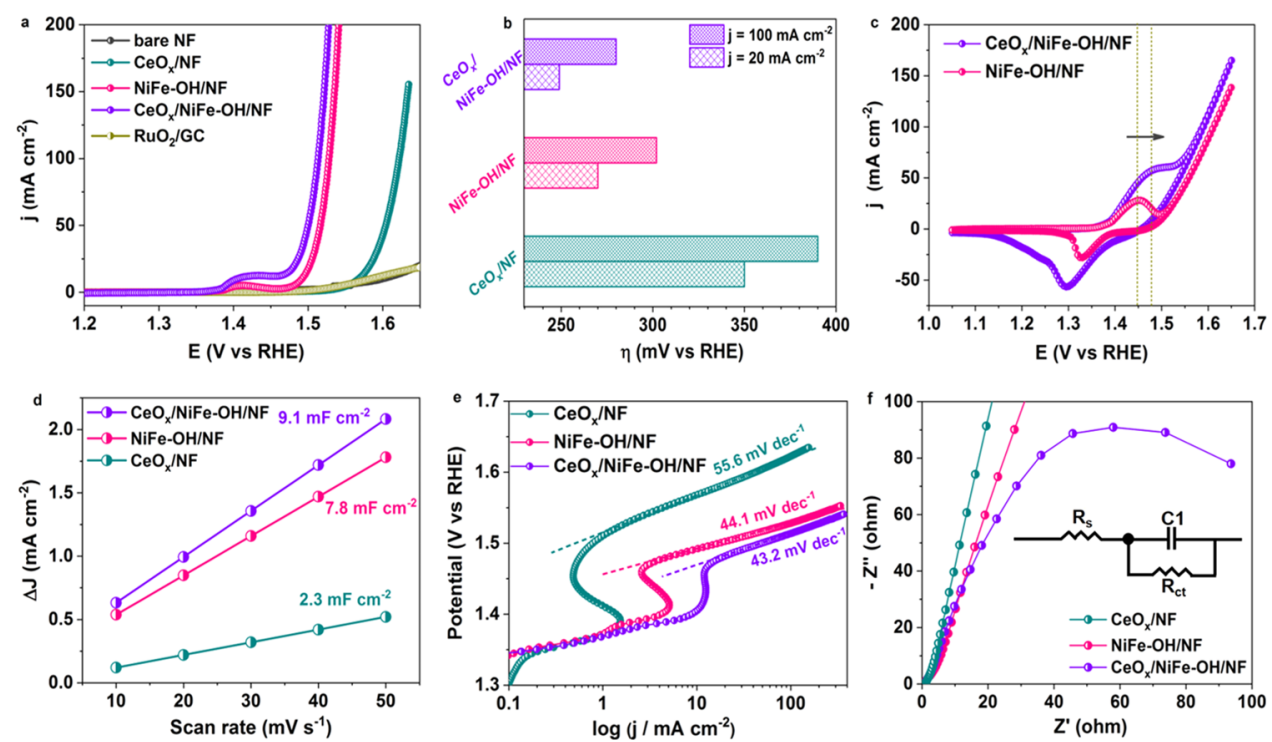

Figure 3. Electrochemical characterization of the prepared catalysts. (a) Polarization curves after $i R$ correction show the OER performance of $\mathrm{CeO}_{x} / \mathrm{NiFe}-\mathrm{OH} / \mathrm{NF}$ compared to that of $\mathrm{NiFe}-\mathrm{OH} / \mathrm{NF}, \mathrm{CeO}_{x} / \mathrm{NF}$, bare $\mathrm{NF}$, and commercial $\mathrm{RuO}_{2} / \mathrm{GC}$ in an alkaline solution of $1 \mathrm{M} \mathrm{KOH}$ (pH $\sim$ 13.8). (b) Overpotential $(\eta)$ required for $J=20$ and $100 \mathrm{~mA} \mathrm{~cm}^{-2}$. (c) Cyclic voltammetry curves $(\mathrm{CV})$ of $\mathrm{CeO} x / \mathrm{NiFe}-\mathrm{OH}$ and $\mathrm{NiFe}-\mathrm{OH}$ catalysts. (d) Differences in the charging current density $\left(J_{\mathrm{a}}-J_{\mathrm{c}}\right)$ plotted against scan rates. The linear fitting slope, approximating twice the double-layer capacitance $\left(\mathrm{C}_{\mathrm{dl}}\right)$, was used to represent the electrochemical active surface area. (e) Tafel plots of $\mathrm{CeO} x / \mathrm{NiFe}-\mathrm{OH} / \mathrm{NF}, \mathrm{NiFe}-\mathrm{OH} /$ $\mathrm{NF}$, and $\mathrm{CeO}_{x} / \mathrm{NF}$ recorded in (a). (f) Nyquist plots of different electrocatalysts recorded at $1.45 \mathrm{~V}$ vs RHE.

The decrease in the overpotential apparently corresponded to the introduction of the $\mathrm{CeO}_{x}$ species, which enhanced the overall activity of $\mathrm{CeO}_{x} / \mathrm{NiFe}-\mathrm{OH} / \mathrm{NF}$. In addition, the obtained potential of $\mathrm{CeO}_{x} / \mathrm{NiFe}-\mathrm{OH} / \mathrm{NF}$ at $100 \mathrm{~mA} \mathrm{~cm}$ was even less than those of the state-of-the-art catalysts of $\mathrm{IrO}_{2}$ and $\mathrm{RuO}_{2}$, and it was even considerably less than those of the most reported $\mathrm{CeO}_{2}$ - and $\mathrm{NiFe}-\mathrm{OH}$-based catalysts (Figure $\mathrm{S} 3$, Table S1). To investigate the origin of the high catalytic activity of the $\mathrm{CeO}_{x} / \mathrm{NiFe}-\mathrm{OH} / \mathrm{NF}$ film, cyclic voltammetry (CV) curves were recorded (Figure 3c). Both catalysts (i.e., $\mathrm{CeO}_{x} / \mathrm{NiFe}-\mathrm{OH} / \mathrm{NF}$ and $\mathrm{NiFe}-\mathrm{OH} / \mathrm{NF}$ ) exhibited protoncoupled electron-transfer reactions of the $\mathrm{Ni}^{\mathrm{II}} / \mathrm{Ni}^{\mathrm{III}}$ redox. Oxidation reactions possibly occurred as follows. $34,37-39$
Step-1: Surface oxidation

$$
\begin{aligned}
& \mathrm{Ni}^{2+}-\mathrm{Fe}^{3+}-\mathrm{Ce}^{3+}+\mathrm{OH}_{\text {sol }}^{-} \\
& \quad \leftrightarrow\left(\mathrm{OH}^{-}\right)_{i e}-\mathrm{Ni}^{3+}-\mathrm{Fe}^{3+}-\mathrm{Ce}^{3+}+\mathrm{e}^{-}
\end{aligned}
$$

Step-2: Hydroxide adsorption

$$
\begin{gathered}
\left(\mathrm{OH}^{-}\right)_{\text {ie }}-\mathrm{Ni}^{3+}-\mathrm{Fe}^{3+}-\mathrm{Ce}^{3+}+\mathrm{OH}_{\text {sol }}^{-} \leftrightarrow\left(\mathrm{OH}^{-}\right)_{\text {ie }} \\
-\mathrm{Ni}^{3+}-\mathrm{Fe}^{3+}-\mathrm{Ce}^{4+}-\mathrm{OH}_{\mathrm{ads}}^{-}+\mathrm{e}^{-}
\end{gathered}
$$

Step-3: Charge transfer 

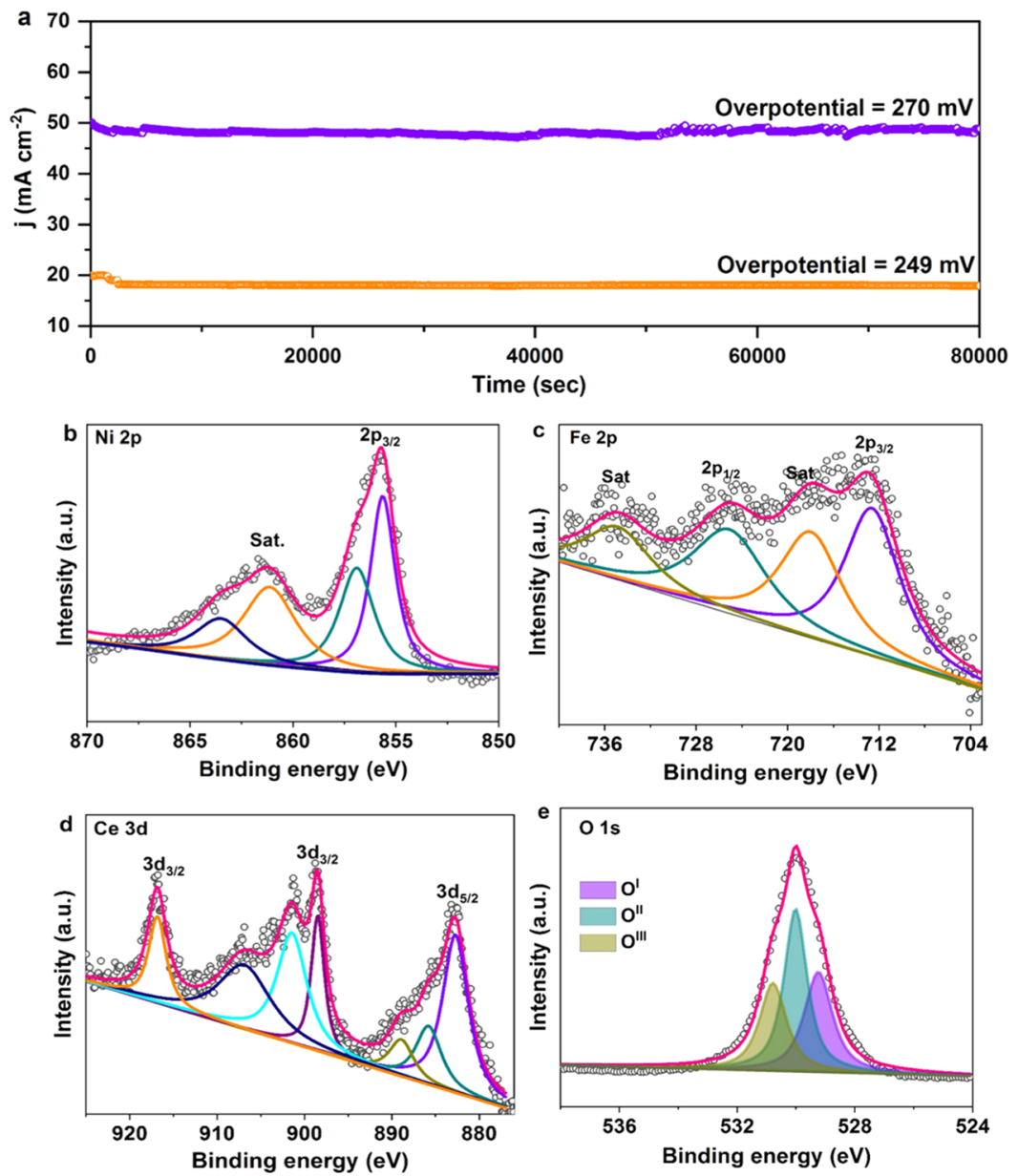

Figure 4. Stability and postcatalytic characterization. (a) Long-term stability measurements of $\mathrm{CeO}_{x} / \mathrm{NiFe}-\mathrm{OH} / \mathrm{NF}$ for $80000 \mathrm{~s}$ at constant potentials of 249 and $270 \mathrm{mV}$ for current densities of 20 and $50 \mathrm{~mA} \mathrm{~cm}^{-2}$, respectively. The chemical state in $\mathrm{CeO}_{x} / \mathrm{NiFe}-\mathrm{OH} / \mathrm{NF}$ (after stability) was examined by XPS analysis. (b) Ni 2p, (c) $\mathrm{Fe} 2 \mathrm{p}$, (d) Ce $3 \mathrm{~d}$, and (e) $\mathrm{O} 1 \mathrm{~s}$ spectra. $\mathrm{O}^{\mathrm{I}}, \mathrm{O}^{\mathrm{II}}$, and $\mathrm{O}^{\mathrm{III}}$ correspond to the oxide ions $(\mathrm{CeO})_{x}$, hydroxide ions $\left(\mathrm{OH}^{-}\right)$, and lattice oxygen $\left(\mathrm{O}^{2-}\right)$ on the $\mathrm{CeO}_{x} / \mathrm{NiFe}-\mathrm{OH} / \mathrm{NF}$ electrocatalyst surface.

$$
\begin{aligned}
& \left(\mathrm{OH}^{-}\right)_{\mathrm{ie}}-\mathrm{Ni}^{3+}-\mathrm{Fe}^{3+}-\mathrm{Ce}^{4+}-\mathrm{OH}_{\mathrm{ads}}^{-}+\mathrm{OH}_{\mathrm{sol}}^{-} \\
& \quad \leftrightarrow\left(\mathrm{OH}^{-}\right)_{\mathrm{ie}} \\
& -\mathrm{Ni}^{3+}-\mathrm{Fe}^{3+}-\mathrm{Ce}^{4+}+\frac{1}{2} \mathrm{O}_{2}+\mathrm{H}_{2} \mathrm{O}+2 \mathrm{e}^{-}
\end{aligned}
$$

After the incorporation of $\mathrm{CeO}_{x}$, a positive shift toward the anodic direction was observed, favoring the increment of the $\mathrm{Ni}^{2+} / \mathrm{Ni}^{3+}$ transformation, and an extremely large amount of highly oxidative cation species was formed in the $\mathrm{CeO}_{x} / \mathrm{NiFe}-$ $\mathrm{OH}$ film (Figure 3c). ${ }^{40,41}$ Moreover, we have also investigated the extent of the $\mathrm{Ni}^{2+} / \mathrm{Ni}^{3+}$ transformation by integrated oxidation peak areas of $\mathrm{CeO}_{x} / \mathrm{NiFe}-\mathrm{OH}$ and $\mathrm{NiFe}-\mathrm{OH}$ film. ${ }^{18}$ As shown in Figure $\mathrm{S} 4, \mathrm{CeO}_{x} / \mathrm{NiFe}-\mathrm{OH}$ was found to have more oxidative cation species as compared to $\mathrm{NiFe}-\mathrm{OH}$ and eventually yield better electrocatalytic activity in OER. In addition, the embedded $\mathrm{CeO}_{x}$ boosted surface-oxygen ion exchange and electron interactions between neighboring atoms caused by the multivalence state of $\mathrm{CeO}_{x}$, while $\mathrm{Fe}^{3+}$ enhanced the hydroxide adsorption and generated surface defects for coordination species. ${ }^{17,41}$ The above-mentioned aspects can lead to the enhancement of the OER catalytic activity. The electrochemical double-layer capacitance $\left(\mathrm{C}_{\mathrm{dl}}\right)$ values for the $\mathrm{CeO}_{x} / \mathrm{NiFe}-\mathrm{OH}, \mathrm{NiFe}-\mathrm{OH}$, and $\mathrm{CeO}_{x}$ films on NF electrodes were estimated to be $9.1,7.8$, and $2.3 \mathrm{mF} \mathrm{cm}^{-2}$, respectively (Figures $3 \mathrm{~d}$ and $\mathrm{S} 5$ ). This result indicated that the incorporation of $\mathrm{CeO}_{x}$ into $\mathrm{NiFe}-\mathrm{OH}$ leads to the formation of more active sites than in the control samples, and this larger surface coverage of active sites is one of the reasons for the better OER activity of the $\mathrm{CeO}_{x} / \mathrm{NiFe}-\mathrm{OH}$ film. By the incorporation of the $\mathrm{CeO}_{x}$ species, the aggregation of interfacial oxygen defects is expected to be enhanced in oxide-based electrocatalysts. ${ }^{23}$ To further understand the catalytic kinetics of the as-prepared catalyst, Tafel slopes determined from the polarization plots of Figure 3a are shown in Figure $3 \mathrm{e} . \mathrm{CeO}_{x} / \mathrm{NiFe}-\mathrm{OH} / \mathrm{NF}$ films also exhibited the

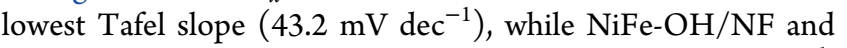
$\mathrm{CeO}_{x} / \mathrm{NF}$ exhibited Tafel slopes of 44.1 and $55.7 \mathrm{mV} \mathrm{dec}^{-1}$, respectively, confirming more rapid OER kinetics for the $\mathrm{CeO}_{x} / \mathrm{NiFe}-\mathrm{OH} / \mathrm{NF}$ films. This conclusion can be further examined by electrochemical impedance spectroscopy (EIS). The charge-transfer resistance $\left(R_{c t}\right)$ of $\mathrm{CeO}_{x} / \mathrm{NiFe}-\mathrm{OH}$ was less than those of $\mathrm{NiFe}-\mathrm{OH}$ and $\mathrm{CeO}_{x}$ films, indicating that $\mathrm{CeO}_{x} / \mathrm{NiFe}-\mathrm{OH}$ exhibits a considerably higher electron transport ability for OER (Figure 3f). Furthermore, to examine the stability of the $\mathrm{CeO}_{x} / \mathrm{NiFe}-\mathrm{OH}$ catalyst, chronoamperometric measurements were carried out for $80000 \mathrm{~s}$ at constant applied potentials of $249 \mathrm{mV}\left(20 \mathrm{~mA} \mathrm{~cm}^{-2}\right)$ and $270 \mathrm{mV}$ (50 $\mathrm{mA} \mathrm{cm}{ }^{-2}$ ). The $\mathrm{CeO}_{x} / \mathrm{NiFe}-\mathrm{OH}$ films exhibit negligible degradation during continuous operation over $80000 \mathrm{~s}$, confirming their excellent stability as can be seen in Figure 
4a. Also, we performed 5000 continuous cyclic voltammograms (CVs) for the $\mathrm{CeO}_{x} / \mathrm{NiFe}-\mathrm{OH}$ catalyst between 1.2 to $1.7 \mathrm{~V}$ vs RHE. The linear sweep voltammetry (LSV) curves of $\mathrm{CeO}_{x} / \mathrm{NiFe}-\mathrm{OH}$ before and after $5000 \mathrm{CVs}$ were identical with each other, which further confirm their excellent durability. (Figure S6). The surface morphology of $\mathrm{CeO}_{x} / \mathrm{NiFe}-\mathrm{OH}$ (Figure S7a,b) still maintained a homogenous distribution of $\mathrm{CeO}_{x} / \mathrm{NiFe}-\mathrm{OH}$ on NF after the stability test of $80000 \mathrm{~s}$ at an overpotential of $249 \mathrm{mV}$. XPS results (Figures $4 \mathrm{~b}-\mathrm{e}$ and S8) revealed no obvious change in the electronic interactions between $\mathrm{CeO}_{x}$ and $\mathrm{NiFe}-\mathrm{OH}$, confirming the high structural stability of the $\mathrm{CeO}_{x} / \mathrm{NiFe}-\mathrm{OH}$ catalyst.

Furthermore, the amount of $\mathrm{O}_{2}$ released on the $\mathrm{CeO}_{x} / \mathrm{NiFe}$ $\mathrm{OH} / \mathrm{NF}$ electrode as a function of time was examined at a constant current density of $4 \mathrm{~mA} \mathrm{~cm} \mathrm{~cm}^{-2}$ using a Hoffman electrolysis apparatus ${ }^{22}$ and compared with the volumes calculated by theory (see the Supporting Information for the theoretical calculation). Experimental data were in good agreement with the theoretically calculated volumes of $\mathrm{O}_{2}$, indicative of a Faradaic efficiency of nearly greater than $95 \%$ (Figure 5a). In addition, the inherent OER catalytic activities
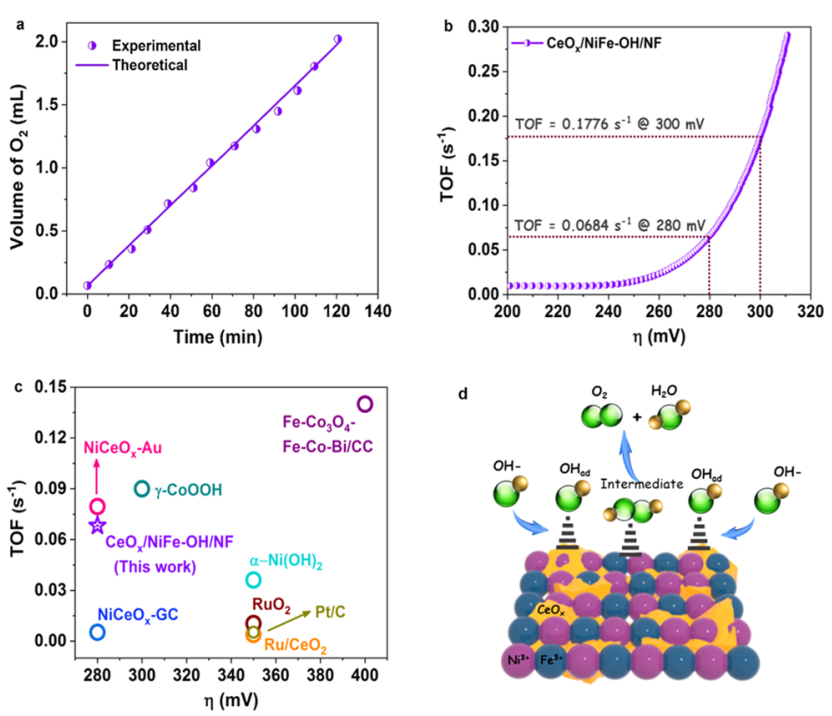

Figure 5. (a) Evolution of $\mathrm{O}_{2}$ gas on the $\mathrm{CeO}_{x} / \mathrm{NiFe}-\mathrm{OH} / \mathrm{NF}$ electrode over $120 \mathrm{~min}$ recorded at $4 \mathrm{~mA} \mathrm{~cm}^{-2}$. (b) $\mathrm{TOF}$ of the asdeposited $\mathrm{CeO}_{x} / \mathrm{NiFe}-\mathrm{OH} / \mathrm{NF}$ electrocatalyst. (c) TOFs of $\mathrm{CeO}_{x} /$ $\mathrm{NiFe}-\mathrm{OH} / \mathrm{NF}$ compared with those of the recently reported transition-metal-based catalysts such as $\mathrm{NiCeO}_{x}-\mathrm{Au}$ (ref 4a), $\mathrm{NiCeO}_{x}-\mathrm{GC}$ (ref $\left.4 \mathrm{a}\right), \alpha-\mathrm{Ni}(\mathrm{OH})_{2}$ (ref 17), $\gamma$-CoOOH (ref 18 ), $\mathrm{Pt} / \mathrm{C}$ (ref 17), $\mathrm{Fe}-\mathrm{Co}_{3} \mathrm{O}_{4} @ \mathrm{Fe}-\mathrm{Co}-\mathrm{Bi} / \mathrm{CC}$ (ref 19), $\mathrm{Ru}^{0} / \mathrm{CeO}_{2}$ (ref4h), and $\mathrm{RuO}_{2}$ (ref 17). (c) OER process of the $\mathrm{CeO}_{x} / \mathrm{NiFe}$ $\mathrm{OH}$ catalysts.

of $\mathrm{CeO}_{x} / \mathrm{NiFe}-\mathrm{OH}$ were investigated by the calculation of the turnover frequency (TOF), supposing that almost all of the metal sites participated in the electrochemical reaction. The TOF of $\mathrm{CeO}_{x} / \mathrm{NiFe}-\mathrm{OH}$ was $0.0684 \mathrm{~s}^{-1}$ at an overpotential $(\eta)$ of $280 \mathrm{mV}$ (Figure $5 \mathrm{~b}$ ); this value is reasonably low and comparable to those reported previously (Figure 5c) for transition-metal-oxide-based catalysts, i.e., $\mathrm{NiCeO}_{x}-\mathrm{Au}$ $\left(0.0795 \mathrm{~s}^{-1}\right.$ at $\left.\eta=280 \mathrm{mV}\right),{ }^{15} \mathrm{NiCeO}_{x}-\mathrm{GC}\left(0.0052 \mathrm{~s}^{-1}\right.$ at $\eta=280 \mathrm{mV}),{ }^{15} \alpha-\mathrm{Ni}(\mathrm{OH})_{2}\left(0.0361 \mathrm{~s}^{-1}\right.$ at $\left.\eta=350 \mathrm{mV}\right),{ }^{42} \gamma-$ $\mathrm{CoOOH}\left(0.09 \mathrm{~s}^{-1}\right.$ at $\left.\eta=300 \mathrm{mV}\right){ }^{43} \mathrm{Pt} / \mathrm{C}\left(0.0053 \mathrm{~s}^{-1}\right.$ at $\eta=$ $350 \mathrm{mV}),{ }^{42} \mathrm{Fe}-\mathrm{Co}_{3} \mathrm{O}_{4} @ \mathrm{Fe}-\mathrm{Co}-\mathrm{Bi} / \mathrm{CC}\left(0.14 \mathrm{~s}^{-1}\right.$ at $\eta=400$ $\mathrm{mV}),{ }^{44} \mathrm{Ru}^{0} / \mathrm{CeO}_{2}\left(0.004 \mathrm{~s}^{-1}\right.$ at $\left.\eta=350 \mathrm{mV}\right),{ }^{22}$ and $\mathrm{RuO}_{2}$ $\left(0.0104 \mathrm{~s}^{-1}\right.$ at $\left.\eta=350 \mathrm{mV}\right) .{ }^{42}$ From this collective data, $\mathrm{CeO}_{x} /$
$\mathrm{NiFe}-\mathrm{OH}$ is confirmed to be an efficient electrocatalyst toward water oxidation.

To understand the reason for the enhanced catalytic activity of $\mathrm{CeO}_{x} / \mathrm{NiFe}-\mathrm{OH}$ films, it is crucial to understand the OER mechanism. The most common OER mechanism under alkaline conditions is given below ${ }^{12,45}$

$$
\begin{aligned}
& \mathrm{S}+\mathrm{OH}^{-} \rightarrow \mathrm{SOH}+\mathrm{e}^{-} \\
& \mathrm{SOH}+\mathrm{OH}^{-} \rightarrow \mathrm{SO}+\mathrm{H}_{2} \mathrm{O}+\mathrm{e}^{-} \\
& \mathrm{SO}+\mathrm{OH}^{-} \rightarrow \mathrm{SOOH}+\mathrm{e}^{-} \\
& \mathrm{SOOH}+\mathrm{OH}^{-} \rightarrow \mathrm{S}+\mathrm{O}_{2}+\mathrm{H}_{2} \mathrm{O}+\mathrm{e}^{-}
\end{aligned}
$$

Here, $S$ denotes the active site on the catalyst surface. Notably, the OER activity mainly depended on the electroadsorption energies between the electrocatalyst surface and oxygen intermediates (such as peroxides and superoxides).

Similar to that reported previously, in this study, highly oxidative cations $\left(\mathrm{Ni}^{3+} / \mathrm{Fe}^{3+}\right)$ are also thought to be the main active sites. $^{40,41}$ According to earlier studies based on density functional theory calculations and experimental results, the presence of Fe sites in a conductive host matrix leads to a more disordered local structure as well as an ideal binding energy with oxygen intermediates $(-\mathrm{OH}$ and $-\mathrm{OOH}){ }^{41,46}$ The enhanced OER activity of the $\mathrm{CeO}_{x} / \mathrm{NiFe}-\mathrm{OH}$ catalyst was probably related to the activation of the more conductive $\mathrm{Ni}$ (III)OOH phase (compared to the nonconductive $\mathrm{Ni}(\mathrm{II})$ $\mathrm{OH}$ phase) and to the charge-transfer effects from the $\mathrm{CeO}_{x}$ species (Figure 5d). Doping with $\mathrm{CeO}_{x}$ also shortened the bond distance of the host lattice $(\mathrm{NiFe}-\mathrm{OH})$ due to the higher oxidation state, thereby yielding the optimized bond strength of $\mathrm{S}-\mathrm{OH} / \mathrm{S}-\mathrm{OOH}$ and leading to the optimal OER performance.

\section{CONCLUSIONS}

In summary, a $3 \mathrm{D}$ porous network of a $\mathrm{CeO}_{x} / \mathrm{NiFe}-\mathrm{OH}$ electrode on NF was successfully fabricated by two-step simple electrodeposition. The electrochemical OER performance of the as-synthesized electrode revealed high catalytic activity by achieving a high current density of $100 \mathrm{~mA} \mathrm{~cm}$ at an overpotential of $280 \mathrm{mV}$, with a low Tafel slope of $43.2 \mathrm{mV}$ $\mathrm{dec}^{-1}$. The high catalytic activity corresponded to the embedding of $\mathrm{CeO}_{x}$ into $\mathrm{NiFe}-\mathrm{OH}$, leading to the modulation of the electronic structures of catalytic active sites. Besides the good catalytic activity, the electrode also exhibited excellent stability in an alkaline medium. Working with $\mathrm{CeO}_{x}$-based catalysts, advantages such as a large amount of surface-active sites, reduced size of catalyst, and lower regulation of $\mathrm{Ce}-\mathrm{O}$ and $\mathrm{Ce}-\mathrm{Ce}$ to promote the activation of adsorbed water can be exploited. Therefore, developing catalysts with $\mathrm{CeO}_{x}$ is expected to be beneficial for industrial-level water splitting.

\section{EXPERIMENTAL SECTION}

Materials. Precursors such as iron(III) nitrate nonahydrate $\left(\mathrm{Fe}\left(\mathrm{NO}_{3}\right)_{3} \cdot 9 \mathrm{H}_{2} \mathrm{O}\right)$, nickel(II) nitrate hexahydrate $\left(\mathrm{Ni}\left(\mathrm{NO}_{3}\right)_{2}\right.$. $\left.6 \mathrm{H}_{2} \mathrm{O}\right)$, cerium (III) nitrate hexahydrate $\left(\mathrm{Ce}\left(\mathrm{NO}_{3}\right)_{3} \cdot 6 \mathrm{H}_{2} \mathrm{O}\right)$, ammonium acetate $\left(\mathrm{CH}_{3} \mathrm{COONH}_{4}\right)$, and potassium hydroxide $(\mathrm{KOH})$ pellets obtained from Sigma-Aldrich were used as received. Nickel foam (>99.99\%, $80 \mu \mathrm{m}$ ) was acquired from MTI Korea. The entire experiment was performed using Milli Q water with a conductivity of $18.2 \mathrm{M} \Omega \mathrm{cm}^{-1}$.

Electrodeposition of the $\mathrm{CeO}_{x} / \mathrm{NiFe}-\mathrm{OH} / \mathrm{NF}$ Film. The $\mathrm{CeO}_{x} /$ $\mathrm{NiFe}-\mathrm{OH}$ film on nickel foam (NF) was prepared by electrodeposition according to a method described elsewhere. ${ }^{26,29}$ In a 
typical procedure, NF $\left(2 \times 4 \mathrm{~cm}^{2}\right)$ was initially subjected to ultrasonication in a $3 \mathrm{M} \mathrm{HCl}$ solution for $20 \mathrm{~min}$ to eliminate unwanted surface-oxide layers. The acid-treated NF was eroded with water and ethanol and subsequently dried in air. A three-electrode cell assembly was used for deposition in which NF, Pt gauze, and saturated $\mathrm{Ag} / \mathrm{AgCl}$ were used as the working, counter, and reference electrodes, respectively. An aqueous solution of $3 \mathrm{mM} \mathrm{Fe}\left(\mathrm{NO}_{3}\right)_{3}$. $9 \mathrm{H}_{2} \mathrm{O}$ and $3 \mathrm{mM} \mathrm{Ni}\left(\mathrm{NO}_{3}\right)_{2} \cdot 6 \mathrm{H}_{2} \mathrm{O}$ was used as the electrolyte solution. The deposition potential was maintained at $-1.0 \mathrm{~V}$ (vs Ag/ $\mathrm{AgCl}$ ) for $300 \mathrm{~s}$ at ambient temperature. After deposition, the substrate NF was carefully removed from the electrolyte, washed with water, and immersed in a freshly prepared aqueous solution of $\mathrm{Ce}\left(\mathrm{NO}_{3}\right)_{3}(0.1 \mathrm{M})$ and ammonium acetate $(0.1 \mathrm{M})$ under argon. Prior to the deposition of $\mathrm{CeO}_{x}$, the electrolyte bath was prepared using a $0.1 \mathrm{M}$ ammonium acetate solution, and after complete dissolution, the aqueous solution was bubbled with Ar for $60 \mathrm{~min}$ to remove the dissolved oxygen in the solution. Then, the $0.1 \mathrm{M}$ $\mathrm{Ce}\left(\mathrm{NO}_{3}\right)_{3}$ solution was included under constant magnetic stirring for $15 \mathrm{~min}$ to ensure homogeneity. The above-mentioned anodic electrolysis was carried out at a constant potential of $+0.5 \mathrm{~V}$ vs Ag/ $\mathrm{AgCl}$ for 600 s. The film thus formed was referred to as $\mathrm{CeO}_{x} / \mathrm{NiFe}-$ $\mathrm{OH}$. Finally, the resultant electrodeposited NF was appropriately removed from the deposition bath, rinsed with water and ethanol, and dried under hot air conditions. The loaded catalyst was weighed using a high-precision microbalance (CAS analytical balance, CAX200). The starting and final weights of NF were calculated before and after the deposition of the $\mathrm{CeO}_{x} / \mathrm{NiFe}-\mathrm{OH}$ catalysts. The loading of the measured $\mathrm{CeO}_{x} / \mathrm{NiFe}-\mathrm{OH}$ catalyst was $\sim 1.92 \mathrm{mg} \mathrm{cm}^{-2}$. For comparison, $\mathrm{NiFe}-\mathrm{OH} / \mathrm{NF}$ and $\mathrm{CeO}_{x} / \mathrm{NF}$ films were also prepared under the same procedure in the absence of the respective deposition bath.

For comparison, the OER performance of noble-metal catalyst $\mathrm{RuO}_{2}$ on a glassy carbon (GC) electrode was studied using a procedure (drop-casting method) similar to that reported in our previous work. ${ }^{10}$ Briefly, $12 \mathrm{mg}$ of the $\mathrm{RuO}_{2}$ powders was dispersed in a $2 \mathrm{~mL}$ mixture solution $(120 \mu \mathrm{L}$ of $5 \%$ Nafion solution, $800 \mu \mathrm{L}$ of deionized water, and $1.08 \mathrm{~mL}$ of ethanol) and then the mixture was continually sonicated for $30 \mathrm{~min}$ to form a stable suspension. Eventually, $6 \mu \mathrm{L}$ of obtained ink was dropped on the GC electrode and dried in ambient air. The amount of $\mathrm{RuO}_{2}$ onto the GC electrode was $2 \mathrm{mg} \mathrm{cm}^{-2}$.

Material Characterization. XRD patterns were recorded on a Rigaku X-ray diffractometer with a $\mathrm{Cu} \mathrm{K} \alpha$ emission wavelength $\lambda$ of $1.514 \mathrm{~A}^{\circ}$. XPS profiles were recorded on a Thermo VG scientific Xray photoelectron spectrophotometer. The morphology, elemental distribution, and composition were examined by field-emission scanning electron microscopy (HITACHI S-4800 microscope) and HR-TEM (JEOL JEM-2100F microscope) analyses.

Electrochemical Characterization. OER analyses were conducted in a $1 \mathrm{M} \mathrm{KOH}\left(\mathrm{O}_{2}\right.$ saturated $)$ solution using a Gamry Reference 3000 electrochemical workstation at room temperature. In a standard three-electrode cell, a graphite rod, $\mathrm{Hg} / \mathrm{HgO}$ (in $1 \mathrm{M}$ $\mathrm{NaOH}$ ), and electrodeposited $\mathrm{CeO}_{x} / \mathrm{NiFe}-\mathrm{OH}, \mathrm{NiFe}-\mathrm{OH}$, and $\mathrm{CeO}_{x}$ on NF were used as the counter, reference, and working electrodes, respectively. The reference electrode was calibrated against a reversible hydrogen electrode (RHE), and the applied potential values were converted to the RHE scale using the following equation: $E_{\mathrm{RHE}}=E_{\mathrm{Hg} / \mathrm{HgO}}+0.931 \mathrm{~V}$. All voltages were $i R$ (where $R$ and $i$ represent the electrolyte resistance and current, respectively) amended by EIS $\left(E_{\text {corrected }}=E_{\text {raw }}-i R\right)$, and the LSV curve was recorded at potentials ranging from 1.0 to $1.8 \mathrm{~V}$ vs RHE at a slow and steady scan rate of $5 \mathrm{mV} \mathrm{s}^{-1}$. EIS for electrocatalysts was carried out under $1.45 \mathrm{~V}$ vs RHE (frequency range: $1-100 \mathrm{kHz}, \mathrm{AC}$ signal amplitude: $25 \mathrm{mV}$ ). Chronoamperometry was carried out under the same experimental setup without $i R$ drop compensation. The electrochemical surface area was determined using the capacitive current associated with the double-layer charging from the voltammogram scan rate. $C_{\mathrm{dl}}$ values were employed by plotting the negative and positive current density differences $\left(\Delta j=j_{\mathrm{a}}-j_{\mathrm{c}}\right)$ as a function of the $\mathrm{CV}$ scan rates $\left(10-50 \mathrm{mV} \mathrm{s}^{-1}\right)$ within the electrochemical potential window between 1.10 and $1.20 \mathrm{~V}$ vs RHE. The linear slope is twice of the double-layer capacitance is equal to one half of the linear slope.

\section{ASSOCIATED CONTENT}

\section{Supporting Information}

The Supporting Information is available free of charge on the ACS Publications website at DOI: 10.1021/acssuschemeng.9b03496.

SEM and TEM images; XPS data; cyclic voltammograms; turnover frequency and theoretical volume of oxygen calculation (PDF)

\section{AUTHOR INFORMATION}

\section{Corresponding Authors}

*E-mail: ranjith.bose@ku.ac.ae (R.B.).

*E-mail: hyunseokk@dongguk.edu (H.-S.K.).

*E-mail: akram.alfantazi@ku.ac.ae (A.A.).

ORCID

Ranjith Bose: 0000-0003-4813-6655

Hyun-Seok Kim: 0000-0003-1127-5766

Akram Alfantazi: 0000-0002-4039-5110

Notes

The authors declare no competing financial interest.

\section{ACKNOWLEDGMENTS}

The authors acknowledge the financial support provided by Khalifa University, Abu Dhabi, United Arab Emirates. This work was also supported by the Basic Science Research Program through the National Research Foundation of Korea (NRF) funded by the Ministry of Education (No. 2017R1D1A1A09000823).

\section{REFERENCES}

(1) McCrory, C. C. L.; Jung, S.; Ferrer, I. M.; Chatman, S. M.; Peters, J. C.; Jaramillo, T. F. Benchmarking Hydrogen Evolving Reaction and Oxygen Evolving Reaction Electrocatalysts for Solar Water Splitting Devices. J. Am. Chem. Soc. 2015, 137, 4347-4357.

(2) McCrory, C. C. L.; Jung, S.; Peters, J. C.; Jaramillo, T. F. Benchmarking Heterogeneous Electrocatalysts for the Oxygen Evolution Reaction. J. Am. Chem. Soc. 2013, 135, 16977-16987.

(3) Bose, R.; Jothi, V. R.; Koh, B.; Jung, C.; Yi, S. C. Molybdenum Sulphoselenophosphide Spheroids as an Effective Catalyst for Hydrogen Evolution Reaction. Small 2018, 14, No. 1703862.

(4) Lewis, N. S.; Nocera, D. G. Powering the planet: Chemical challenges in solar energy utilization. Proc. Natl. Acad. Sci. U.S.A. 2006, 103, 15729.

(5) Gust, D.; Moore, T. A.; Moore, A. L. Solar Fuels via Artificial Photosynthesis. Acc. Chem. Res. 2009, 42, 1890-1898.

(6) Chen, C.; Kang, Y.; Huo, Z.; Zhu, Z.; Huang, W.; Xin, H. L.; Snyder, J. D.; Li, D.; Herron, J. A.; Mavrikakis, M.; Chi, M.; More, K. L.; Li, Y.; Markovic, N. M.; Somorjai, G. A.; Yang, P.; Stamenkovic, V. R. Highly Crystalline Multimetallic Nanoframes with Three-Dimensional Electrocatalytic Surfaces. Science 2014, 343, 1339.

(7) Benck, J. D.; Hellstern, T. R.; Kibsgaard, J.; Chakthranont, P.; Jaramillo, T. F. Catalyzing the Hydrogen Evolution Reaction (HER) with Molybdenum Sulfide Nanomaterials. ACS Catal. 2014, 4, 39573971.

(8) Han, L.; Dong, S.; Wang, E. Transition-Metal (Co, Ni, and Fe)Based Electrocatalysts for the Water Oxidation Reaction. Adv. Mater. 2016, 28, 9266-9291.

(9) Song, F.; Bai, L.; Moysiadou, A.; Lee, S.; Hu, C.; Liardet, L.; Hu, X. Transition Metal Oxides as Electrocatalysts for the Oxygen Evolution Reaction in Alkaline Solutions: An Application-Inspired Renaissance. J. Am. Chem. Soc. 2018, 140, 7748-7759. 
(10) Jothi, V. R.; Bose, R.; Rajan, H.; Jung, C.; Yi, S. C. Harvesting Electronic Waste for the Development of Highly Efficient Eco-Design Electrodes for Electrocatalytic Water Splitting. Adv. Energy Mater. 2018, 8, No. 1802615.

(11) Bediako, D. K.; Surendranath, Y.; Nocera, D. G. Mechanistic Studies of the Oxygen Evolution Reaction Mediated by a NickelBorate Thin Film Electrocatalyst. J. Am. Chem. Soc. 2013, 135, 36623674.

(12) Suen, N.-T.; Hung, S.-F.; Quan, Q.; Zhang, N.; Xu, Y.-J.; Chen, H. M. Electrocatalysis for the oxygen evolution reaction: recent development and future perspectives. Chem. Soc. Rev. 2017, 46, 337365.

(13) Zhu, K.; Zhu, X.; Yang, W. Application of In Situ Techniques for the Characterization of NiFe-Based Oxygen Evolution Reaction (OER) Electrocatalysts. Angew. Chem., Int. Ed. 2019, 58, 1252-1265. (14) Bose, R.; Jothi, V. R.; Velusamy, D. B.; Arunkumar, P.; Yi, S. C. A Highly Effective, Stable Oxygen Evolution Catalyst Derived from Transition Metal Selenides and Phosphides. Part. Part. Syst. Charact. 2018, 35, No. 1800135.

(15) Ng, J. W. D.; García-Melchor, M.; Bajdich, M.; Chakthranont, P.; Kirk, C.; Vojvodic, A.; Jaramillo, T. F. Gold-supported ceriumdoped $\mathrm{NiO}_{x}$ catalysts for water oxidation. Nat. Energy 2016, 1, No. 16053.

(16) Paier, J.; Penschke, C.; Sauer, J. Oxygen Defects and Surface Chemistry of Ceria: Quantum Chemical Studies Compared to Experiment. Chem. Rev. 2013, 113, 3949-3985.

(17) Feng, J.-X.; Ye, S.-H.; Xu, H.; Tong, Y.-X.; Li, G.-R. Design and Synthesis of $\mathrm{FeOOH} / \mathrm{CeO}_{2}$ Heterolayered Nanotube Electrocatalysts for the Oxygen Evolution Reaction. Adv. Mater. 2016, 28, 46984703.

(18) Liu, Z.; Li, N.; Zhao, H.; Zhang, Y.; Huang, Y.; Yin, Z.; Du, Y. Regulating the active species of $\mathrm{Ni}(\mathrm{OH})_{2}$ using $\mathrm{CeO}_{2}: 3 \mathrm{D} \mathrm{CeO}_{2} /$ $\mathrm{Ni}(\mathrm{OH})_{2} /$ carbon foam as an efficient electrode for the oxygen evolution reaction. Chem. Sci. 2017, 8, 3211-3217.

(19) Gao, W.; Xia, Z.; Cao, F.; Ho, J. C.; Jiang, Z.; Qu, Y. Comprehensive Understanding of the Spatial Configurations of $\mathrm{CeO}_{2}$ in $\mathrm{NiO}$ for the Electrocatalytic Oxygen Evolution Reaction: Embedded or Surface-Loaded. Adv. Funct. Mater. 2018, 28 , No. 1706056.

(20) Rashid, J.; Parveen, N.; Haq, T.; Iqbal, A.; Talib, S. H.; Awan, S. U.; Hussain, N.; Zaheer, M. g- $\mathrm{C}_{3} \mathrm{~N}_{4} / \mathrm{CeO}_{2} / \mathrm{Fe}_{3} \mathrm{O}_{4}$ Ternary Composite as an Efficient Bifunctional Catalyst for Overall Water Splitting. ChemCatChem 2018, 10, 5587-5592.

(21) Xu, H.; Cao, J.; Shan, C.; Wang, B.; Xi, P.; Liu, W.; Tang, Y. MOF-Derived Hollow CoS Decorated with $\mathrm{CeOx}$ Nanoparticles for Boosting Oxygen Evolution Reaction Electrocatalysis. Angew. Chem. 2018, 130, 8790-8794.

(22) Demir, E.; Akbayrak, S.; Önal, A. M.; Özkar, S. Ceria supported ruthenium $(0)$ nanoparticles: Highly efficient catalysts in oxygen evolution reaction. J. Colloid Interface Sci. 2019, 534, 704-710.

(23) Yu, J.; Cao, Q.; Li, Y.; Long, X.; Yang, S.; Clark, J. K.; Nakabayashi, M.; Shibata, N.; Delaunay, J.-J. Defect-Rich $\mathrm{NiCeO}_{x}$ Electrocatalyst with Ultrahigh Stability and Low Overpotential for Water Oxidation. ACS Catal. 2019, 9, 1605-1611.

(24) Zhao, D.; Pi, Y.; Shao, Q.; Feng, Y.; Zhang, Y.; Huang, X. Enhancing Oxygen Evolution Electrocatalysis via the Intimate Hydroxide-Oxide Interface. ACS Nano 2018, 12, 6245-6251.

(25) Obata, K.; Takanabe, K. A Permselective CeOx Coating To Improve the Stability of Oxygen Evolution Electrocatalysts. Angew. Chem., Int. Ed. 2018, 57, 1616-1620.

(26) Lu, X.; Zhao, C. Electrodeposition of hierarchically structured three-dimensional nickel-iron electrodes for efficient oxygen evolution at high current densities. Nat. Commun. 2015, 6, No. 6616.

(27) Ahn, S. H.; Choi, I.; Park, H.-Y.; Hwang, S. J.; Yoo, S. J.; Cho, E.; Kim, H.-J.; Henkensmeier, D.; Nam, S. W.; Kim, S.-K.; Jang, J. H. Effect of morphology of electrodeposited $\mathrm{Ni}$ catalysts on the behavior of bubbles generated during the oxygen evolution reaction in alkaline water electrolysis. Chem. Commun. 2013, 49, 9323-9325.
(28) Liang, H.; Gandi, A. N.; Xia, C.; Hedhili, M. N.; Anjum, D. H.; Schwingenschlögl, U.; Alshareef, H. N. Amorphous NiFe-OH/NiFeP Electrocatalyst Fabricated at Low Temperature for Water Oxidation Applications. ACS Energy Lett. 2017, 2, 1035-1042.

(29) Kulp, E. A.; Limmer, S. J.; Bohannan, E. W.; Switzer, J. A. Electrodeposition of nanometer-thick ceria films by oxidation of cerium(III)-acetate. Solid State Ionics 2007, 178, 749-757.

(30) Zhao, D.-D.; Bao, S.-J.; Zhou, W.-J.; Li, H.-L. Preparation of hexagonal nanoporous nickel hydroxide film and its application for electrochemical capacitor. Electrochem. Commun. 2007, 9, 869-874.

(31) Yuan, C.; Li, J.; Hou, L.; Zhang, X.; Shen, L.; Lou, X. W. Ultrathin Mesoporous $\mathrm{NiCo}_{2} \mathrm{O}_{4}$ Nanosheets Supported on Ni Foam as Advanced Electrodes for Supercapacitors. Adv. Funct. Mater. 2012, 22, 4592-4597.

(32) Lu, Z.; Li, Y.; Lei, X.; Liu, J.; Sun, X. Nanoarray based "superaerophobic" surfaces for gas evolution reaction electrodes. Mater. Horiz. 2015, 2, 294-298.

(33) Kou, T.; Wang, S.; Hauser, J. L.; Chen, M.; Oliver, S. R. J.; Ye, Y.; Guo, J.; Li, Y. Ni Foam-Supported Fe-Doped $\beta$ - $\mathrm{Ni}(\mathrm{OH})_{2}$ Nanosheets Show Ultralow Overpotential for Oxygen Evolution Reaction. ACS Energy Lett. 2019, 4, 622-628.

(34) Paulraj, A. R.; Kiros, Y.; Göthelid, M.; Johansson, B. M. $\mathrm{NiFeOx}$ as a Bifunctional Electrocatalyst for Oxygen Reduction (OR) and Evolution (OE) Reaction in Alkaline Media. Catalysts 2018, 8, No. 328.

(35) Martin, D.; Duprez, D. Mobility of Surface Species on Oxides. 1. Isotopic Exchange of $18 \mathrm{O}_{2}$ with $16 \mathrm{O}$ of $\mathrm{SiO}_{2}, \mathrm{Al}_{2} \mathrm{O}_{3}, \mathrm{ZrO}_{2}, \mathrm{MgO}$, $\mathrm{CeO}_{2}$, and $\mathrm{CeO}_{2}-\mathrm{Al}_{2} \mathrm{O}_{3}$. Activation by Noble Metals. Correlation with Oxide Basicity. J. Phys. Chem. A. 1996, 100, 9429-9438.

(36) Mogensen, M.; Sammes, N. M.; Tompsett, G. A. Physical, chemical and electrochemical properties of pure and doped ceria. Solid State Ionics 2000, 129, 63-94.

(37) Oliver-Tolentino, M. A.; Vázquez-Samperio, J.; ManzoRobledo, A.; González-Huerta, R.D.; Flores-Moreno, J. L.; RamírezRosales, D.; Guzmán-Vargas, A. An Approach to Understanding the Electrocatalytic Activity Enhancement by Superexchange Interaction toward OER in Alkaline Media of Ni-Fe LDH. J. Phys. Chem. C 2014, 118, 22432-22438.

(38) Louie, M. W.; Bell, A. T. An Investigation of Thin-Film Ni-Fe Oxide Catalysts for the Electrochemical Evolution of Oxygen. J. Am. Chem. Soc. 2013, 135, 12329-12337.

(39) Castro, E. B.; Gervasi, C. A. Electrodeposited Ni-Co-oxide electrodes:characterization and kinetics of the oxygen evolution reaction. Int. J. Hydrogen Energy 2000, 25, 1163-1170.

(40) Bates, M. K.; Jia, Q.; Doan, H.; Liang, W.; Mukerjee, S. ChargeTransfer Effects in $\mathrm{Ni}-\mathrm{Fe}$ and $\mathrm{Ni}-\mathrm{Fe}-\mathrm{Co}$ Mixed-Metal Oxides for the Alkaline Oxygen Evolution Reaction. ACS Catal. 2016, 6, 155161.

(41) Zhang, W.; Wu, Y.; Qi, J.; Chen, M.; Cao, R. A Thin NiFe Hydroxide Film Formed by Stepwise Electrodeposition Strategy with Significantly Improved Catalytic Water Oxidation Efficiency. Adv. Energy Mater. 2017, 7, No. 1602547.

(42) Gao, M.; Sheng, W.; Zhuang, Z.; Fang, Q.; Gu, S.; Jiang, J.; Yan, Y. Efficient water oxidation using nanostructured $\alpha$-nickelhydroxide as an electrocatalyst. J. Am. Chem. Soc. 2014, 136, 70777084.

(43) Gong, M.; Li, Y.; Wang, H.; Liang, Y.; Wu, J. Z.; Zhou, J.; Wang, J.; Regier, T.; Wei, F.; Dai, H. An Advanced Ni-Fe Layered Double Hydroxide Electrocatalyst for Water Oxidation. J. Am. Chem. Soc. 2013, 135, 8452-8455.

(44) Zhu, G.; Ge, R.; Qu, F.; Du, G.; Asiri, A. M.; Yao, Y.; Sun, X. In situ surface derivation of an $\mathrm{Fe}-\mathrm{Co}-\mathrm{Bi}$ layer on an $\mathrm{Fe}$-doped $\mathrm{Co}_{3} \mathrm{O}_{4}$ nanoarray for efficient water oxidation electrocatalysis under nearneutral conditions. J. Mater. Chem. A 2017, 5, 6388-6392.

(45) Lu, F.; Zhou, M.; Zhou, Y.; Zeng, X. First-Row Transition Metal Based Catalysts for the Oxygen Evolution Reaction under Alkaline Conditions: Basic Principles and Recent Advances. Small 2017, 13, No. 1701931. 
(46) Goldsmith, Z. K.; Harshan, A. K.; Gerken, J. B.; Vörös, M.; Galli, G.; Stahl, S. S.; Hammes-Schiffer, S. Characterization of NiFe oxyhydroxide electrocatalysts by integrated electronic structure calculations and spectroelectrochemistry. Proc. Natl. Acad. Sci. U.S.A. 2017, 114, 3050. 